\title{
Phase-contrast Observations of Interkinetic Nuclei Movements in Cells of Tissue Cultures
}

\author{
Vladimir Püża and Jan Gayer \\ Department of General Biology, Faculty of Medicine, Charles \\ University in Hradec Králové, ČSSR
}

Received June 27, 1966

\section{Introduction}

The interkineitc nucleus is one of the most active components of the cell. However, its activity is also manifestated morphologically - either in relation to products originated in the nucleus and transferring to the cytoplasm or in relation to other causes and that is by its movements. The nuclei movements were described in plant cells by Penard (1902) and by Valkanov(1934). In the tissue culture cells, which are unordinarily suitable for this aim, Pomerat(1953) described the nuclei rotation phenomenon in the nasal mucous cells and the same year Hintsche and Schenker in the mouse kidney papilla epithelium cells. We were occupied by this question (Pủža $1964 \mathrm{a}, \mathrm{b}, 1965$ and 1966, Pủža, Jel'nek and Foglová 1964) and we confirmed that the nuclei of in vitro cultured cells either swing or rotate around their axis. It may be a pantypic phenomenon but its causes are still unknown.

\section{Materials and methods}

The phenomenon which is the subject of our communication was studied either on some permanent cell lines cultured in vitro /L-fibroblasts, PK, KB, FL, HeLa/ or on cells of primocultures obtained by cutting and trypsining of skeletal muscles $/ \mathrm{mm}$. pectorales and femoral muscles/ of 12-day chick embryos. The method was studied in more detail in the previous communications Půža $(1963,1965)$. The cells were cultured in Roux's bottles of Sialglass. By trypsinisation obtained cell suspension in tissue culture medium composed of 80 volume parts of Parker's medium 199, 20 parts of inactivated veal serun, 1, 2, parts of $0.001 \%$ phenol red in $7.5 \%$ solution of natrium bicarbonate and antibiotics $10.01 \mu \mathrm{g}$ PNC and $0.1 \mu \mathrm{g}$ $\mathrm{SMC}$ in $1 \mathrm{ml}$ of mixture/was poured into Petri dishes on the cover glasses $5 \times 5 \mathrm{~mm}$. Just before the observation, the cover glass was taken out, put on the carry-cover-glass so that its non -cell side was just against the carry-glass and the cells were covered by a high drop of the cultivate mixture. Afterwards Maximow's chamber was made up when the preparate was covered by the under-glass with a low anticorrosive steel ring put on its center and kept on the glass by sterile vaseline. In such hermetically closed chamber the cells live during the microscopic observation till 7 days. The cells were observed in the permanent temperature $37-38^{\circ} \mathrm{C}$ and exposed at regular intervals in phase-contrast microscope by $\mathrm{Phv} 40 \times$ objective and projective occulars/6.3: 1 and $4: 1 /$ Carl Zeiss Jena on the $35 \mathrm{~mm}$ cinefilm.

\section{Observations}

The first collection of microphotographs (Fig. 1) shows the life of HeLa cells culture of about 24 hours (time 0 ). As seen on them, the nucleus of the higher situated left cell rotates, while the nucleus of the lower one stays without movement although the shape of its nucleolus changes, especially in the period until 3 hours and 50 minutes at the beginning of the observation. The nucleus of the right cell con- 
tains two nucleoli, one of which (time 0 ) detachs the narrow prominence towards the caryotheca. On the next photograph of this series some moderate rotation of the nucleus can be seen. This motion most clearly occured $35 \mathrm{mi}$ nutes after the

beginning of the observation. At this interval, connection between the nucleolus and the caryotheca interrupts, but it reforms again in the next photograph (45 minutes) where the moderate right rotation can be seen. In the next photographs, the rotation follows. But the whole $360^{\circ}$ rotation did not realise. The nucleus rotates in the opposite direction, as seen in the last photograph (3 hours and 50 minutes). To make the event that has been descripted more clear,each photograph has a schematic

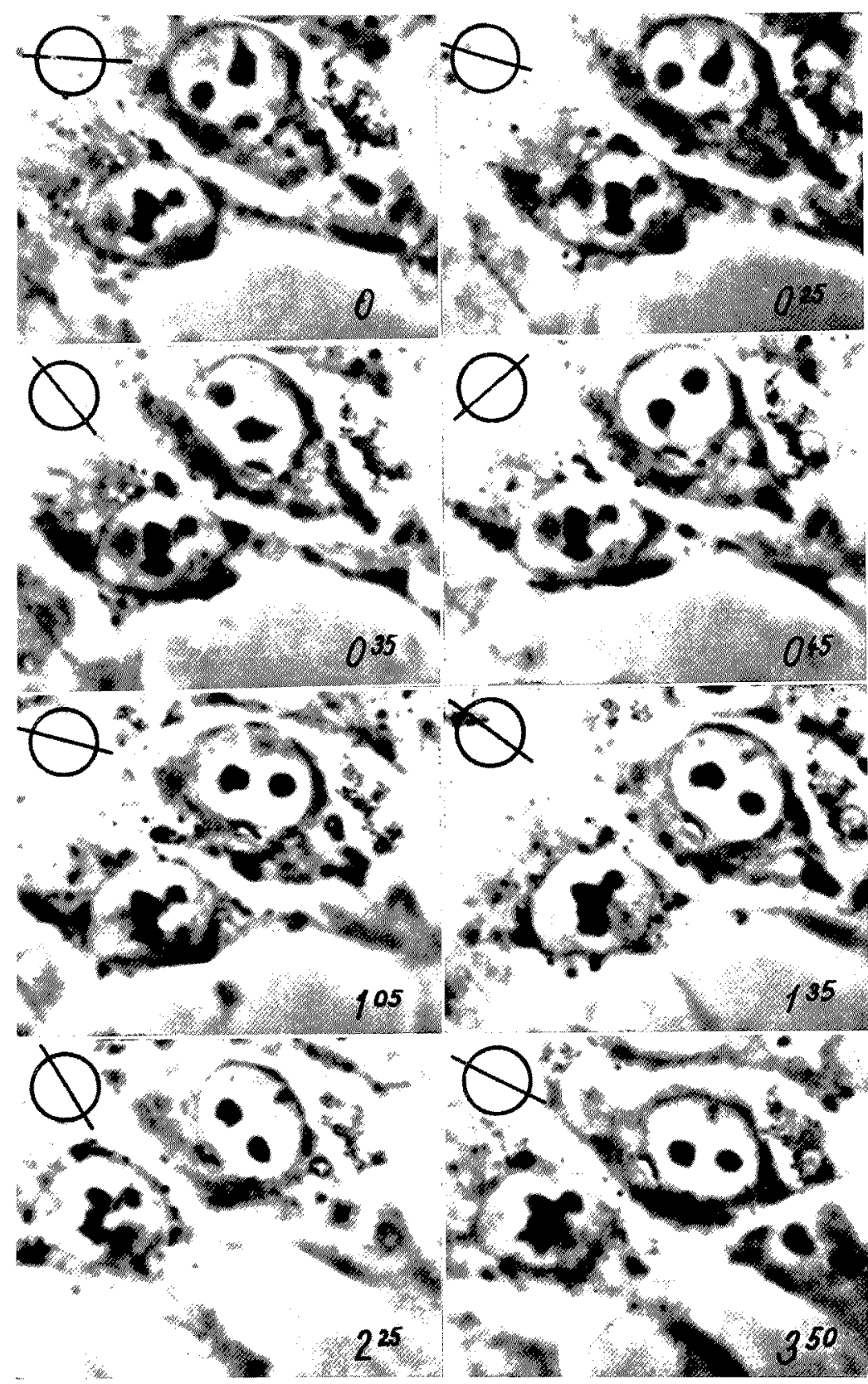

Fig. 1. 24: schematically the upper right nucleus position in time, as written in the down corners of the photographs. The phase-contrast, magnification $\times 843$ 
picture in its upper left corner illustrating the localisation of the long axis of the nucleus.

The group of the microphotographs of the next series (Fig. 2) shows another rotating nucleus of the chick embryonal muscle cell culture 95 hours old. The first nucleolus and later also the second one, are in contact with the caryotheca by mediation of the couplings. The couplings can show the direction of the rotation rather well. The nucleus rotates to the left, but to the right later.

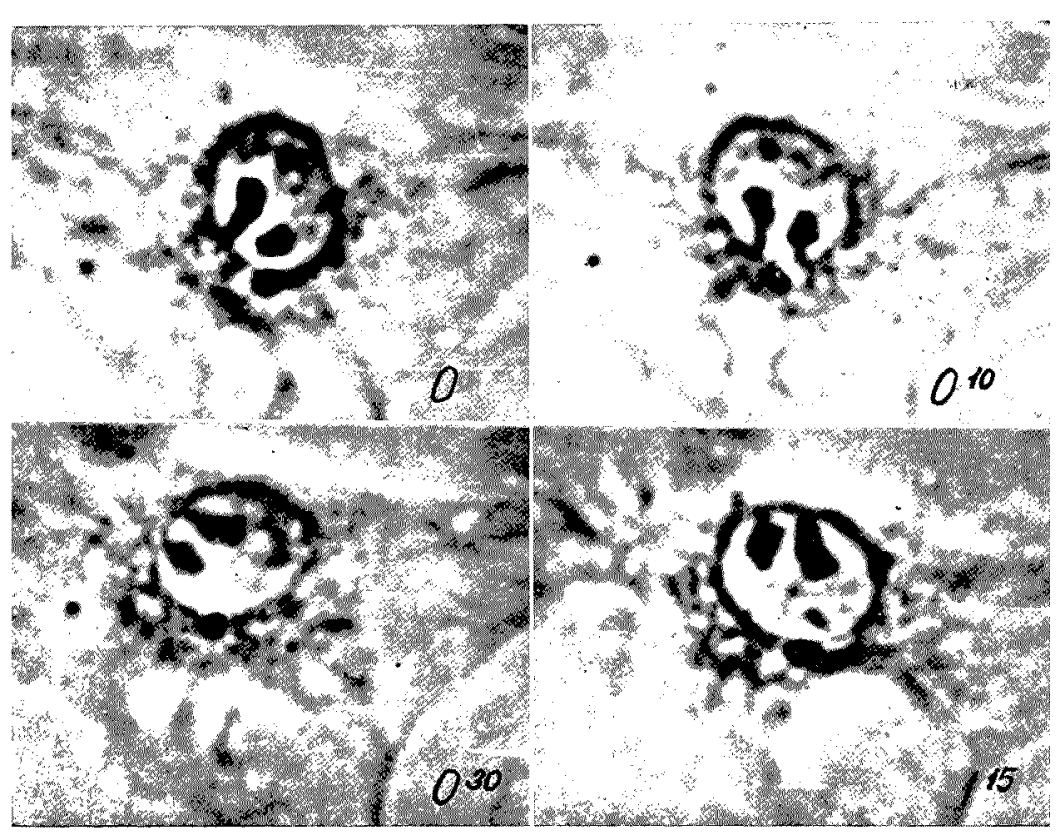

Fig. 2. Rotating nucleus of the chick fibroblast, 72 hours culture. The 9th passage. Phase-contrast, magnification $\times 1000$.
The next series of the photographs (Fig. 3) shows 72 hours HeLa with distinctly formed region corresponding to the Golgi's complex (Rose 1961,GonzálezRamírez et al. (1964) or to the centroplasm region with the Golgi's bodies (Weissenfels 1958). At the first sight, the

number and the localisation of the light secretion vacuoles changes photo by photo in this region. The nucleus of this cell rotates only slowly. In 9 hours and 20 minutes photograph, a vacuole and a coupling toward the caryotheca forms in one of the nucleoli (see arrow) in the same time. In the last photograph of this series, some greater rotation of the nucleus was registered, but the velocity of this movement is not too great, as 15 hours and 20 minutes passed from the previous photograph exposition.

The nucleus of the 88 hours chick fibroblast 9 times passaged in vitro is represented in the next series of the photographs (Fig. 4). The nucleus shows an infolding on its side into which the centroplasm region and the Golgi's complex (see arrow) are impressed. Inside the nucleus, there are two bigger polymorph nucleoli, one of which detachs the coupling towards the caryotheca. On the next photograph of this series (50 minutes) there is clearly shown that the impressed cytoplasm complex passed towards the right pole of the nucleolus which rotated as if some pressure changes had been occured. In the Golgi's region, two bigger secretion vacuoles occurred. The translocation of the whole complex to the right 
can be seen in the next photographs, especially in the last one, more clearly ( 2 hours and 10 minutes). At that time, the enlargment of the zone corresponding to the Golgi's complex shifting upwards occurred and it caused the rotation of the nucleolus so that its last and the original long axis of direction are in the angle about $90^{\circ} \mathrm{C}$.

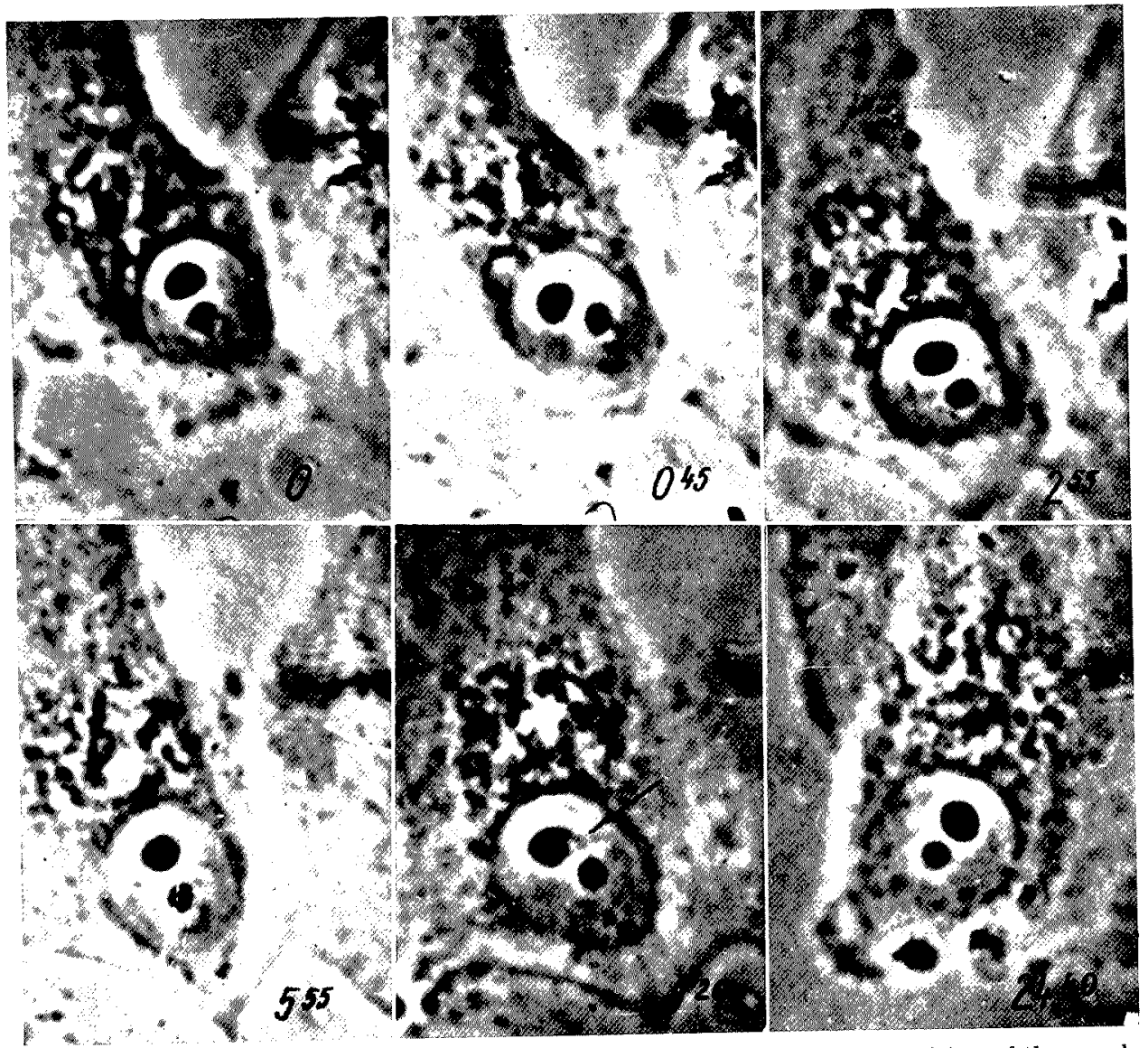

Fig. 3. 72 hours tissue culture HeLa cell. Position of nucleoli shows the position of the nucleus at the same time. Granular cytoplasm of the Golgi's complex contain severe secretion vacuoles, side and distribution of which-changes during the observation. The arrow shows a small vacuole origined in nucleolus. From this vacuole, the coupling to the caryotheca was formed. Time-data in the right lower corner of the photographs. Magnification $\times \mathbf{9 5 3}$

\section{Discussion}

For the cell organells movement observation, the quickly growing cells of tissue cultures in vitro are very suitable, as they ordinarily form the monolayer just on the glass, through which they are able to be seen. The special cultivation methods allow the observations of one cell or one group of cells only for a sufficient long time and that's why the whole series of phenomena passing in cells can be concluded from the dynamics of the morphological changes of the organells. We have mentioned in the introduction that nuclear movements had been observed 
by a number of authors. After the first discoveries made up by Pomerat, . Hintsche and Schenker, during a few years series of works appeared as from these authors' laboratories (Pomerat 1954, 1958, 1961, Hsu 1955, Leone, Hsu and Pomerat 1955, Moorhead and Hsu 1956, Nakai 1956, Quastel and Pomerat 1963, Lefeber 1964, Schenker 1954, Hintsche 1956), as from the others (Capers 1960, Nagata 1960, Cooper and Konigsberg 1961, Falke and Richter 1961, Qulkin and Earle 1962, Rounds 1962, Gropp 1963). All mentioned observations were made up on the cells cultured in tissue cultures in vitro.

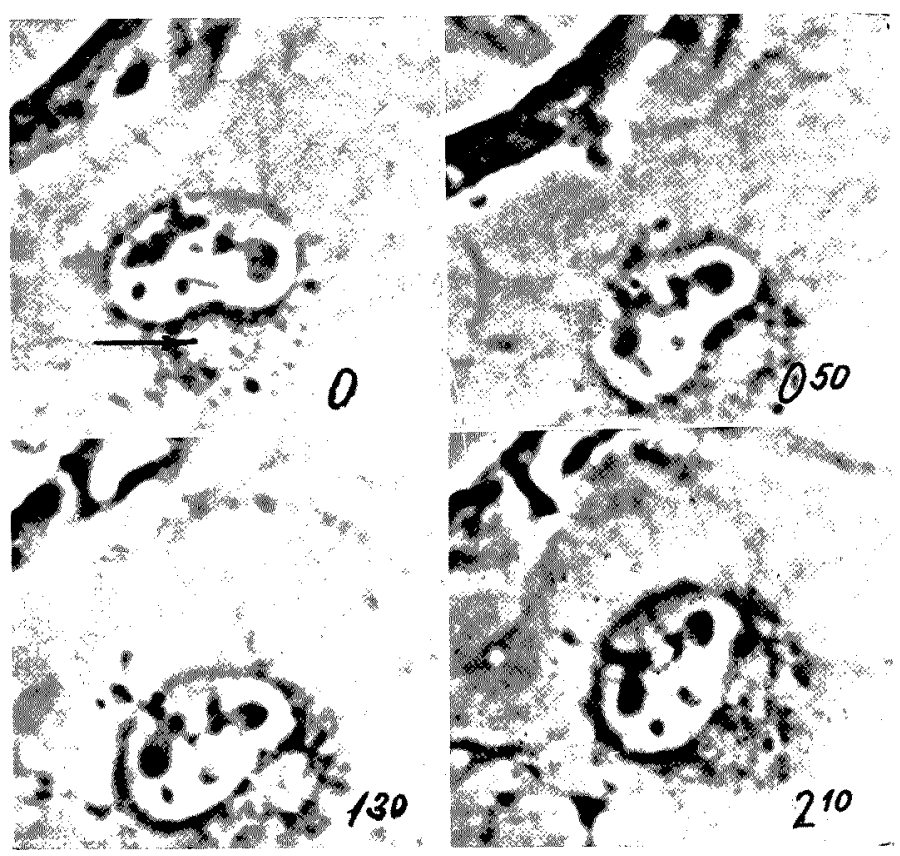

Fig. 4. Chick fibroblast, 88 hours the 9 th passage. The arrow on the second photograph/time $\mathbf{5 0}$ mintues from the beginning of the observation/show the secretion vacuole origining in the Golgi apparatus zone. Phasecontrast, magnfiication $\times 814$.

Capers 1960 and Cooper and Konigsberg 1961 made an effort to explain the apparent amitotic division of the nuclei of the embryonal skeletal muscle cells cultured in vitro The Japanese investigator Nagata documents the similar phenomenon on the chick fibroblasts by a long series of the time-lapse microphotographs. These authors suggest that the infoldings of the nuclear membrane existing very frequently in the undamaged cells can take such a localisation, as a result of the nuclear rotations, that their projection may imitate constrictions of the nuclei. An interesting observation concernig this problem too, was made up by Rose (1964). He found, that the $\mathrm{KB}$ cells nuclei which have caryotheca infoldings regularly rotate.

Schenker (1954) used the nuclear rotation movement of the young mouse renal papilla epithelium as test for the X-rays injured cells detection. Hintsche (1956, 1958) made this observation more extensive and he studied the influence of calcium and magnesium ions, $\mathrm{pH}$ concentration, complexon III., and temperature on the nuclear movements. However, these authors did not mention causes of the movements of nuclei.

As for the opinions about the nuclear rotations causes, they are very different one another. E.g. Porter (1961) and Rebhun (1963) suppose the cause of the 
nuclear rotation to be in the endoplasmic reticulum as in the forces transferring system by which the particles movement is directed through the fibrillar structures. Gropp (1963) has another opinion. He suggests mitochondria to be the substrate of this movements. It is Falke's and Richter's opinion (1961) that is more similar to ours. They suggest nuclear rotations to be in close relation to the metabolism and the cause of this movements to be either in the nucleus itself or, more probably, in the caryotheca, movement of which is followed by the gelous nuclear volume. As they did not find the corresponding movement of the circumnuclear cytoplasmic granules, they refuse any participation of the cytoplasm in this movement. They support their hypothesis either in the corresponding or in the contrary movements of the nuclei in the multinuclear cells. In one of the previous reports we made up the conformable observation (Pưža 1964) in multinuclear cells, which entitled us to suggest the nuclear rotation to the active movement in the close relation to phenomena taking part in the nucleus or in the nucleolus. Rose (1964) outlined his hypothesis that nuclear rotation may be caused by the intranuclear inclusions rotations. In our previous works (Půža 1964, 1965) in agreement with some authors (Pomerat 1958, Johnson and Jones 1962, GonzálezRamírez 1962) we suggested rotatory movements of nucleus to be provoked by the nucleolar secretion into the circumnuclear cytoplasm, as had been described on the tissue cultures by González-Ramírez (1959, 1962, 1963), Lettér and Siebs (1961), Knoth (1964), Weissenfels (1964) and Magrot et al. (1965). That was because we found the extrusions of the nucleolar masses in some cases, after which rotation of the nucleus followed Puža(1964). The similar phenomenon was registered also by González-Ramírez (1963) on his time-lapse microphotographs of the extrusioning nucleolus/see Figs. 8a-f of his communciation or Orr (1965) in the chick embryonal otocyst (Figs. 4 and 5 of his communication) although he did not mention this phenomenon.

Rose (1965) and Gonzâlez-Ramírez (1964) demonstrated either by the living cells phase contrast observation or by the vital dying and by the cytochemical reactions, the Golgi's apparatus changes in its shape and side in consequence of the function activity. Then its morphological and functional changes are the expression of the metabolic activity of cell. Agreeing with it, Rounds (1962) suggest the nuclear rotation to be caused by the Golgi's apparatus secretion activity. In fact, in some cases we saw the formations identical with those that had been described by Rose and González-Ramírez as the Golgi's complex pressed the nucleus out of its some other more or less probable mechanisms either for this or for the other cases. Actually, the close relation with the cell metabolism is indisputable, as the same influences which accelerate it (e.g. the temperature Schenker 1954) accelerate the nuclear rotation and make the possibility of the observation higher, and vice versa, the nuclear rotations are decelerated, or fully troubled by the metabolism inhibitors (e.g. X-rays Schenker 1954, Pomerat 1958, Quastel and Pomerat (1963). 
In addition, we suggest that findings of the nuclear rotations may be in some contrary to the traditional hypothesis about connection of the caryotheca with the endoplasmic membranes and about connection of the latter one with the cytoplasmic membrane of the whole cell. As for it, two possible explanations are offered: Either, the nuclear rotation is false, and only the caryoplasmic volume but not the whole nucleus rotates. This hypothesis is excluded e.g. by the perinuclear corpuscle movement corresponding to the nuclear rotatory one (Půža 1964b). Or, when the endoplasmic-caryotheca connection is rigid in fact, the rotatory movement of the nucleus can not be eternal in the same direction. May be, it corresponds to the such frequent findings of the swinging movements.

\section{Conclusion}

Some cases of the rotation or the swinging movements of nuclei of in vitro cultured cells were described. Close connection of the nuclear rotations and the metabolism, i.e. the secretion activity either of the nucleolus or of the Golgi's apparatus was submitted. Both mechanisms may take part.

\section{Literature}

Capers, Ch. R. 1960. Multinucleation of skeletal muscle in vitro. J. Biophys. Biochem. Cytol. 7: 559-566.

Cooper, W.G. and Konigsberg I.R. 1961. Dynamics of myogensis in vitro. Anat. Rec. 140: 195206.

Falke, D. und Richter I.E. 1961. Mikrokinematographische Studien über die Entstehung von Riesenzellen durch Herpes-B-Virus in Zellkulturen. II. Mitteilung: Morphologisches Verhalten und Bewegungen der Kerne. Arch. Virusforsch. 11 : 86-99.

González-Ramírez, J. 1962. Nucleolar physiology. Time lapse cinemicrography of nucleoli from living HeLa cells and monocytic leukemia J-111. 2nd Ann. Meeting Amer. Soc. Cell Biol. p. 59 (abstr.)

- 1963. Considerations on nuclear physiology, the importance of time lapse cinematography. In: Cinemicrography in cell biology. /Ed. G.G. Rose/ p. 429-443 Acad. Press. Inc. New York.

- Sanchez, M.C. and Oritz, R.M. 1964. Cytological studies I. Golgi apparatus in HeLa cells. Observation of living cells by phase contrast microscopy compared with classical techniques. Bol. Inst. Est. Med. Biol. México 22: 393-401.

- Zuniga, Nunez, B.A. 1959. Nucleolar physiology. I. Passage of two different nucleolar components toward the cytoplasm in living cells. Biol. Inst. Med. Biol. México 17: $61-57$.

Gropp, A. 1963. Morphologie und Verhalten lebender Zellen. Med. Welt 1963: 20-23.

Hintzsche, E. 1956. Kernrotation und Kerngrosse von Epithelkulturen aus Nierenpapillen junger Mäuse. Z. Zellforsch. 43: 526-542.

- und Schenker, H. 1953. Die Wirkung von Röntgenstrahlen auf Epithelkulturen in vitro. Acta Anat. 19: 389 (Abstr.)

Hsu, T.C. 1955. Mammalian chromosomes in vitro. VI. Observations on mitosis with phase cinematography. J. Natl. Cancer Inst. 16: 691-707.

Knoth, W. 1964. Zur Morphologie und Dynamik der Nucleolen in vitro gezüchteter Fibroblasten. Zugleich ein Beitrag zur Differenzierung karyo- und cytoplasmatischer Einschlüsse. II. Mitteilung. Extrusion und cytoplasmatische Lagerung der Nucleolen. Arch. klin. exp. Dermatol. 220: 303-320.

Lefeber, C.G. 1964. Time-lapse cine technique in biology and medicine. J. SMPTE 73: 631-634, 
Leone, V., Hsu, T.C. and Pomerat, C.M. 1955. Cytological studies on HeLa, a strain human cervical carcinoma. On rotatory movements of the nuclei. z. Zellforsh. 41: 481492.

Lettré, R. und Siebs, W. 1961. Some studies on the nucleolus of cells cultivated in vitro.Path. Biol. 9: 819-823.

Magrot, T., Fakan, F. and Bednar, O. 1965. The observation of extrusion of nucleolar substance in HeLa cells. Fol. Morph. 13: 239-245.

Moorhead, P.S. and Hsu, T.C. 1956. Cytologic studies of HeLa, a strain of human cervical carcinoma. III. Durations and characteristics of the mitotic phases. J. Nat. Cancer Inst. 16: 1047-1066.

Nagata, T. 1960. Observation on the nuclear transformation of chick fibroblasts in tissue culture as revealed by time-lapse cinematography. Med. J. Shinshu Univ. 5: 265-285.

Nakai, J. 1956. Dissociated dorsal root ganglia in tissue culture. Am. J. Anat. 99: 81-129.

Orr, M.F. 1965, Development of acoustic ganglia in tissue cultures of embyronic chick otocyst. Exp. Cell Res. 40:68-77

Penard, E. 1943. Faune rhizopodique du bassin du Lémon. 1902, see Valkanov 1934.

Pomerat, C.M. -953. Rotating nuclei in tissue cultures of adult human nasal mucosa. Exp. Cell Res. 5 : 191-195.

- 1954. Living human histology. XV. Congr. Soc. Int. Chir. Lison, Sept. 1953, p. 236-256, Smedt, Bruxelles 1954.

- 1958. Cinematographic analysis of cell dynamics. Fed. Proc. 17: 975-984.

- 1961. Cinematography, indispensable tool for cytology, Int. Rev. Cytol. 11: 307-334.

Porter, K.R., 1961. See Rebhun (1963).

Pủża, V. 1963. Lebendbeobachtungen der Amitose in der Gewebekultur. Z. Zellforsch. 61: 159-167.

- 1964. Functional changes of the nucleoli observed in vivo. Čsl. morf. 12: 16-29.

- 1964. Motions of interkinetic nuclei of cells in tissue cultures. Caryol. 17: 347-359.

- 1965. Some remarks on the cause of nuclear rotation. Fol. Morph. 13: 27-30.

- 1966. Phase contrast observation of motions of cell nuclei. Coll. Sci. Works Fac.

Med. Charles University Hradec Králové 9: 393-393.

- Jelinek, A. und Foglová, V. 1964. Beobachtung über Kernrotation in Gewebekulturen.

Z. mikr. -anat. Forsch. 71: 114-120.

Quastel, M.R. and Pomerat, C.M. 1963. Irradiation of cells in tissues culture. VIII. Morphological observation of neurons following cobalt-60 gamma irradiation of dorsal root ganglia from the newborn rat. Z. Zellforsch. 59: 214-223.

Mc Quilkin, W.T. and Earl, W.R. 1962. Cinemicrographic analysis of cell populations in vitro. J. Nat. Canc. Inst. 28: 763-799.

Rebhun, L.I. 1963. Saltatory particle movements and their relation to the mitotic apparatus. In: The cell in mitosis (ed. L. Levine), p. 67-106. Acad. Press, New York and London.

Rose, G.G. 1961. The Golgi complex in living osteoblasts. J. Biophys. Biochem. Cytol. 9: 463478.

- 1964. Nuclear folds versus intranuclear inclusions tissue cultures. J. Roy. micr. Soc., Ser. 3, 83 : $377-390$

Rounds, D.E. 1962. Aspects of the mechanism and function of nuclear rotation. 2nd Ann. Meeting Amer. Soc. Cell Biol. p. 159 (abstr.)

Schenker, H. 1954. Frühwirkung von Röntgenstrahlen auf Epithelkulturen in vitro. Z. mikr. anat. Forsch. 60: 589-612.

Valkanov, A. 1934. Über die kinetische Energie einiger Zellbestandteile. Protoplasma 20: 20-30.

Weissenfels, N. 1959. Golgi-Körper im phasenkontrast und elektronenmikroskopischen Bild von Hühnerherzmyoblasten. Naturwiss. 46233.

- 1964. Struktur und Verhalten der Nukleolen von Hühnerherzmyoblasten in Gewebekultur während des Interphasenwachstums und der Mitose. Z. Zellforsch. 62: 667-700. 